University of Nebraska - Lincoln

DigitalCommons@University of Nebraska - Lincoln

\title{
Causes of wolf depredation increase in Minnesota from
}

\section{9-1998}

Elizabeth K. Harper

University of Minnesota, St. Paul

William J. Paul

United States Department of Agriculture, APHIS Wildlife Services

L. David Mech

USGS Northern Prairie Wildlife Research Center, david_mech@usgs.gov

Follow this and additional works at: https://digitalcommons.unl.edu/usgsnpwrc

Part of the Other International and Area Studies Commons

Harper, Elizabeth K.; Paul, William J.; and Mech, L. David, "Causes of wolf depredation increase in Minnesota from 1979-1998" (2005). USGS Northern Prairie Wildlife Research Center. 95.

https://digitalcommons.unl.edu/usgsnpwrc/95

This Article is brought to you for free and open access by the US Geological Survey at DigitalCommons@University of Nebraska - Lincoln. It has been accepted for inclusion in USGS Northern Prairie Wildlife Research Center by an authorized administrator of DigitalCommons@University of Nebraska - Lincoln. 


\title{
Causes of wolf depredation increase in Minnesota from 1979-1998
}

\author{
Elizabeth K. Harper, William J. Paul, and L. David Mech
}

Abstract Wolf (Canis lupus) depredations on livestock in Minnesota have been increasing over the last 20 years. A major explanation cited for this increase is wolf range expansion, but no studies have tested this explanation. Additional reasons could include 1) wolf colonization of new areas within long-existing wolf range, 2) learning by wolves in established range, and 3 ) increased wolf density. We did not assess increasing wolf density as a factor because estimated wolf density in Minnesota has not increased. To assess how each of the other factors might have affected depredations, we created and analyzed a database of Minnesota's 923 verified depredations at 435 farms. We graphed the numbers of verified depredations and the number of farms with verified depredations to assess temporal trends and used ArcView GIS software to assess spatial relationships of the depredations. All 3 factors tested (colonization, range expansion, and learning) seemed to have contributed to wolf depredation increase. However, the proportion of depredations occurring due to wolf range expansion increased from $20 \%$ in 1989 to $48 \%$ in 1998.

Key words Canis lupus, cattle, control, depredations, endangered species, livestock, populations, sheep, wolf

Wolf populations have been expanding their range in several areas of the 48 contiguous states as a result of protection by the Endangered Species Act and reintroduction by the federal government. As wolf range has expanded, wolf depredations on livestock have increased. However, as wolf range expands, at least 3 other factors also might contribute to increased depredations: 1) increased wolf density, 2) wolf colonization of new areas within existing wolf range, and 3) learning. Thus, it is of interest to analyze the causes of wolf depredation increase in an area with a long history of such. Minnesota's wolf population has increased enough that wolves currently are being evaluated for removal from the Endangered Species List (United States Fish and Wildlife Service [USFWS] 2003). From winter 1988-1989 to winter 1997-1998, the population grew from an estimated 1,500 to 2,450 (Berg and Benson 1999). Wolves expanded south- ward and westward by $48 \%$ (Berg and Benson 1999), saturating wilderness and semi-wilderness areas (Mech 1998). This expansion increased the number of wolves in agricultural lands (Fuller et al. 1992; Mech 2001) and areas where road and human densities were believed to be too high to sustain wolf populations without considerable conflict with humans (USFWS 1978, 1992; Berg and Benson 1999). During this same period, livestock depredations by wolves increased (Fritts 1982; Fritts et al. 1992; Paul 1998, 2000).

The reason most frequently cited for this increase in depredations has been wolf range expansion (Fritts et al. 1992; Mech 2000, 2001; Mech et al. 2000), and evidence can be seen in the increasing depredations along the northwestern and southwestern edge of the Minnesota wolf range (Paul 1998). However, no analysis of the possible effect of factors other than range expansion

Address for Elizabeth K. Harper: Department of Fisheries, Wildlife and Conservation Biology, University of Minnesota, 1980 Folwell Ave., St. Paul, MN 55108, USA. Address for William J. Paul: United States Department of Agriculture, APHIS Wildlife Services, 34912 U.S. Hwy 2, Grand Rapids, MN 55744, USA. Address for L. David Mech: United States Geological Survey, Northern Prairie Wildlife Research Center, 8711 37th St. SE, Jamestown, ND 58401, USA; mailing address: The Raptor Center, 1920 Fitch Ave., University of Minnesota, St. Paul, MN 55108,USA; e-mail: david_mech@usgs.gov. 
on wolf depredation increase has been done. We attempted to determine whether any of the other factors mentioned above affected wolf depredation increase. Our null hypothesis was that only wolf range expansion caused the increase.

\section{Study area}

Wolf range in Minnesota was restricted to the wilderness of the Superior National Forest until the early 1970s, when it began expanding (Fuller et al. 1992). As it expanded southwestward from its saturated wilderness reservoir, individual wolf packs colonized disjunct areas of semi-wilderness and isolated habitats within agricultural land (Fuller et al. 1992, Berg and Benson 1999). Thus, current wolf range consists of both large saturated regions in the northeastern third of Minnesota and regions of scattered wolf populations and individual packs immediately south and west of this area (Berg and Benson 1999).

\section{Methods}

We created and analyzed a database of verified wolf depredation data from 1979 to 1998 using data compiled by agencies responsible for lethal control of depredating wolves. These agencies are the USFWS (1979-1985) and United States Department of Agriculture, Animal Plant Health Inspection Service, Wildlife Services (WS) (1986-1998). The data included information on the location (township, range, and section) of farms with verified depredation complaints, type of livestock killed, and dates USFWS and WS trapped in response to the depredations. To ensure that the data we used were based on depredations caused by wolves, we only used data from complaints that government personnel had verified were attributable to wolves. If there was any doubt that a wolf had killed the livestock (even if considered probable), we did not include the data. Because of this approach, numbers reported here may differ from those presented elsewhere (Fritts 1982; Fritts et al. 1992; Paul 1998, 2000). We considered multiple complaints at the same farm as separate events for most analyses. We used only complaints involving cattle, sheep, or turkeys. The data included 923 verified depredations at $\mathbf{4 3 5}$ different farms.

Because we excluded some depredation complaints used in previous analyses, we reanalyzed the temporal and spatial distribution of the remaining

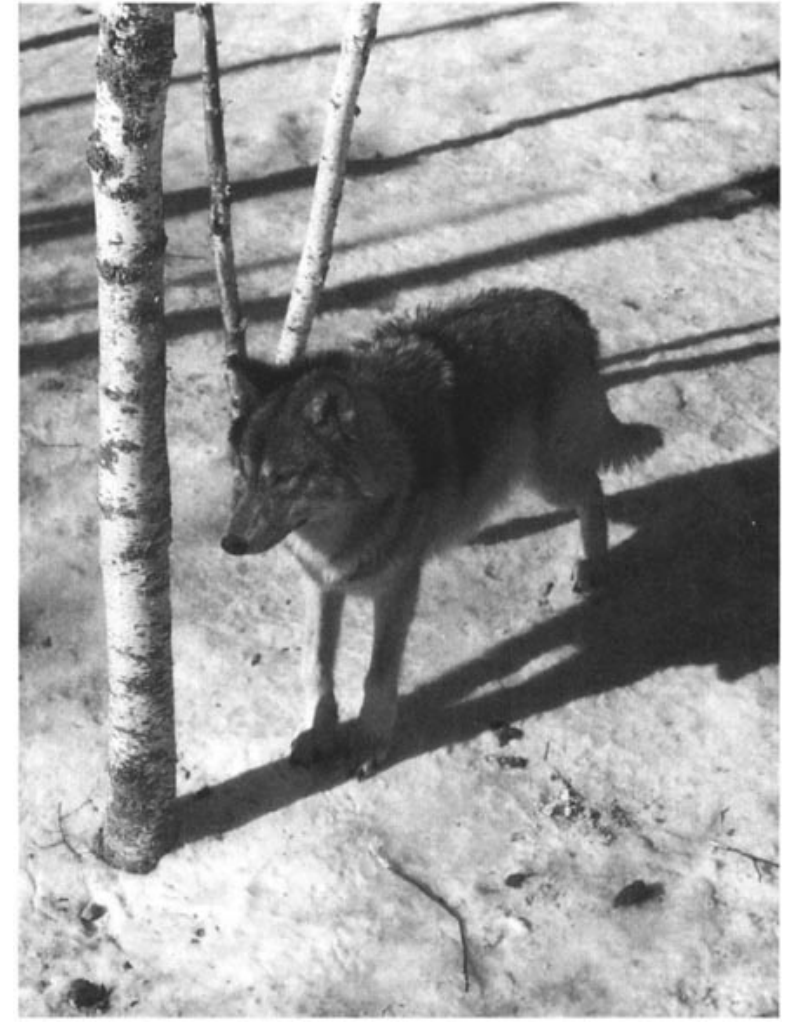

Wolves have increased in numbers and range in Minnesota since the early 1970s, now reaching 2,500-3,000 animals.

complaints and affected farms to ensure that the increases seen by others (Fritts 1982; Fritts et al. 1992; Paul 1998) for an earlier period were still reflected in our larger dataset. The dataset of verified wolf depredations used in these analyses is essentially an entire population rather than a sample; thus, any differences or trends seen were real and not due to sampling error. Therefore, it was not necessary to do significance testing (Cherry 1998).

\section{Determining changes in temporal and spatial distribution of wolf depredations in Minnesota}

To assess changes in temporal distribution of wolf depredations, we graphed the number of verified depredation complaints and number of farms with verified depredation complaints against time (1978-1998). To determine trends in the spatial distribution of depredations, we utilized ArcView (Environmental Systems Research Institute, Redlands, Calif.) Geographic Information System software (GIS) and its extension Animal Movement (P. N. Hooge and B. Eichenlaub, Biological Science Center, United States Geological Survey, Anchorage, 
Alas.) to 1) map the locations of farms with verified wolf depredations for 1979-1998, 2) create minimum convex polygons (MCP) (Mohr and Stumpf 1966) around each year's depredation sites, 3 ) create MCPs of the depredation sites in 5-year increments starting in 1979 , and 4) calculate the area of all MCPs to represent the area over which wolves preyed on livestock. We did not remove the areas of large lakes or cities for our calculations; therefore, the depredation MCPs represent maximum areas.

We then assessed how much the area of depredations was increasing by calculating the percent increase in area for each 5-year period. We also used the depredation MCPs for 1979, 1989, and 1998 to assess the percent of occupied wolf range that incurred depredations. To do this, we divided the area of each of the 1979, 1989, and 1998 depredation MCPs by the total wolf range estimated by the Minnesota Department of Natural Resources (MNDNR) for the same years (Berg and Benson 1999).

\section{Determining causes for increased livestock depredation in Minnesota}

Expansion of wolf range. The best way to determine the effect of range expansion on wolf depredation would be to compare the area of each year's wolf range with the number of depredations that year. However, Minnesota's wolf range is estimated only once every 10 years, so that was not possible. Instead, we determined the area common to all the annual depredation MCPs from 1989 through 1998, $\left(41,079 \mathrm{~km}^{2}\right)$ (Figure 1) and examined the number of depredations that occurred outside this area from 1989 to 1998 . Any increase in depredations outside this area would be attributable to range expansion.

Wolf colonization of new areas within wolf range. Because further wolf colonization of regions already within occupied wolf range might also contribute to Minnesota's wolf depredation increase, we completed a series of analyses to test this hypothesis. We used ArcView to select the data from farms located inside the 1989-1998 common MCP and then graphed the annual number of verified depredations (1989-1998). We hypothesized that if this number increased inside the depredation MCP, this increase could not be related to wolf range expansion but rather would be due to wolf colonization of areas already within wolf range or to wolves learning to prey more on livestock.

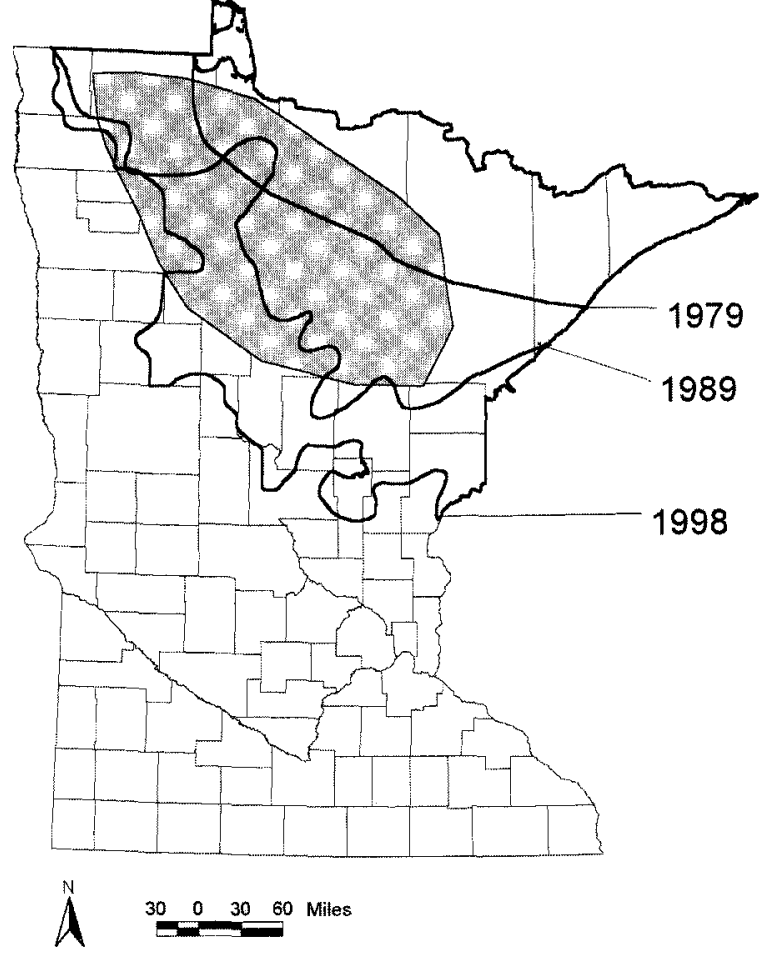

Figure 1. Expansion of Minnesota wolf range and the minimum convex polygon (MCP) common to all annual MCPs enclosing wolf depredations, 1989-1998.

Because we considered each depredation independent of a particular farm, increases in verified depredations within the depredation MCP could be due to increases at farms already suffering depredations (possibly indicating learning), increases in number of farms incurring depredations (indicating wolf colonization of new farms), or to both. To discern how many of the increased depredations were due to wolf colonization of new farms, we graphed the number of farms having depredations each year inside the depredation MCP against year. An increase would indicate that wolves were depredating at more farms in the historical area, not just committing more depredations at the same farms.

Proportion of depredations due to wolf colonization of new areas within occupied wolf range. The analyses described above assess the possibility that depredations were increasing within an area of wolf range expansion, and within existing wolf range, but they do not determine how much each factor contributed. To assess this question, we examined the proportion of depredation complaints inside the depredation MCP each year to see if there was a trend. We assumed that the proportion of depredations inside the depredation 


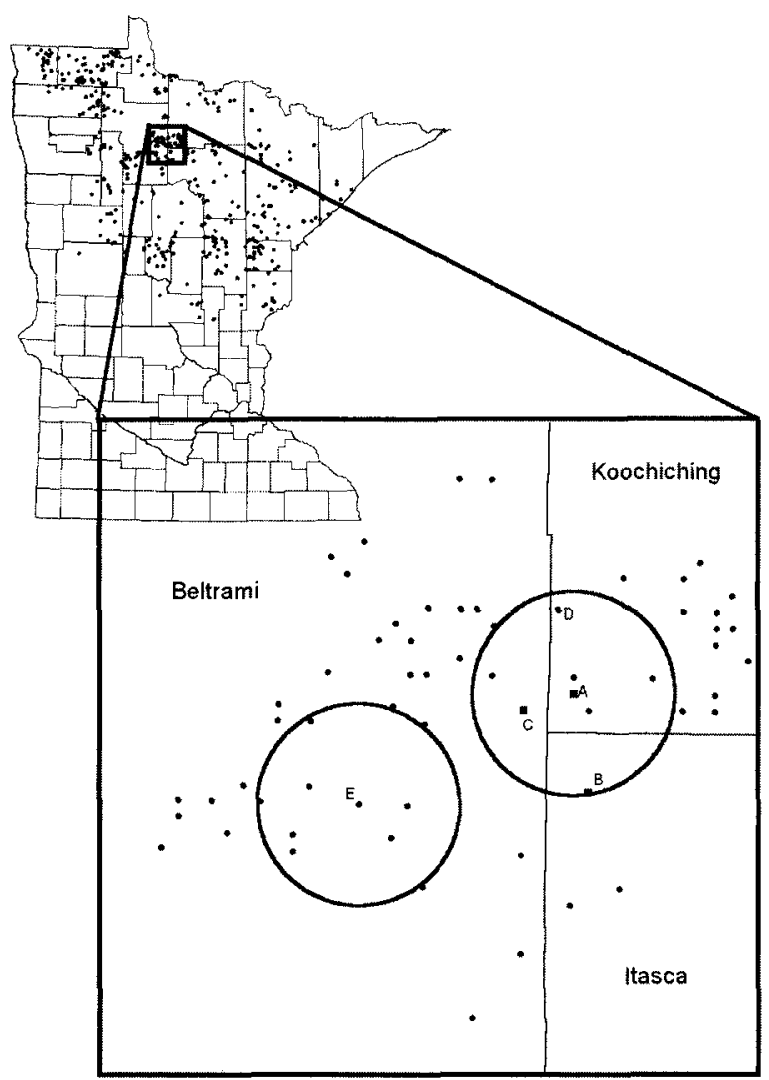

- Farms with 5 or more verified depredations from 1979.1998

- Farms with 1 or more verified depredations from $1979-1998$

County

Figure 2. Locations of Minnesota farms with at least one verified livestock depredation and an expanded view of farm clusters (A-E) with a history of depredations chosen for examination of possible learning by wolves to prey on livestock 1979-1998 (Table 1). Large circles represent areas within $10-\mathrm{km}$ radii of selected center farms $A$ and $E$.

MCP would decrease after the original area occupied by wolves became saturated. We also calculated the mean annual percent increase in depredations inside versus outside the depredation MCP.
Learned behavior of wolves in an area. To assess the possibility of livestock depredation increases resulting from wolves learning to prey on livestock, we analyzed the history of depredations in 2 localized clusters of farms with long histories of depredations (Figure 2 and Table 1). We examined some farms separately and then included farms within $10 \mathrm{~km}$ to see whether any trends were limited to farm-level analysis, or whether learned behavior could be seen at a coarser level.

To eliminate the effects of wolf range expansion for this analysis, all of the farm-cluster combinations were chosen from within the area of historical occurrence of depredations, the 1989-1998 depredation MCP. The 10-km limit to the radius of the farm clusters and the territorial nature of wolves decreased the probability of an effect of an increased number of wolf packs in the regions. Additionally, farm cluster A-C contained farms that all had depredations the first year of this study (1979) (Table 1), eliminating the effects of an increase in the number of farms sustaining depredations. Thus, these farm clusters allowed us to focus on the effects of the possibility of local wolves learning to prey on livestock. To examine possible effects of wolf learning, we created histograms of the number of verified depredations per year for each of these 4 farm clusters. If there was no evidence of local wolves learning to prey on livestock, the number of verified depredations at these farms should remain relatively equal each year, decrease, or be randomly distributed. A general increase would suggest that local wolves were learning to prey more on livestock.

\section{Results}

\section{Changes in temporal and spatial distribution of wolf depredations}

In 1979 only 12\% of wolf range incurred wolf depredations. However by $1989,89 \%$ of wolf range

Table 1. Descriptions of Minnesota farms with a history of verified wolf depredations used for examining the possibility of wolves learning to prey on livestock, 1979-1998.

\begin{tabular}{|c|c|}
\hline Farms & Description \\
\hline$A, B$, and $C$ & $\begin{array}{l}\text { All farms have } \geq 5 \text { verified depredation complaints from 1979-1998 (first depredation in } \\
\text { 1979), and all are within } 10 \mathrm{~km} \text { of } \mathrm{A}\end{array}$ \\
\hline$A, B, C$, and $D$ & Same as above plus farm D with $\geq 5$ verified depredation complaints since 1989 \\
\hline All farms within $10 \mathrm{~km}$ of $\mathrm{A}$ & Same as above plus 5 farms with $\geq 1$ verified depredation complaint since 1979 \\
\hline All farm within $10 \mathrm{~km}$ of $\mathrm{E}^{\mathrm{a}}$ & 2 farms with $>5$ verified depredation complaints since 1989 plus 6 farms with $\geq 1$ since 1979 \\
\hline
\end{tabular}

a Just over $20 \mathrm{~km} \mathrm{SW}$ of $\mathrm{A}$. 


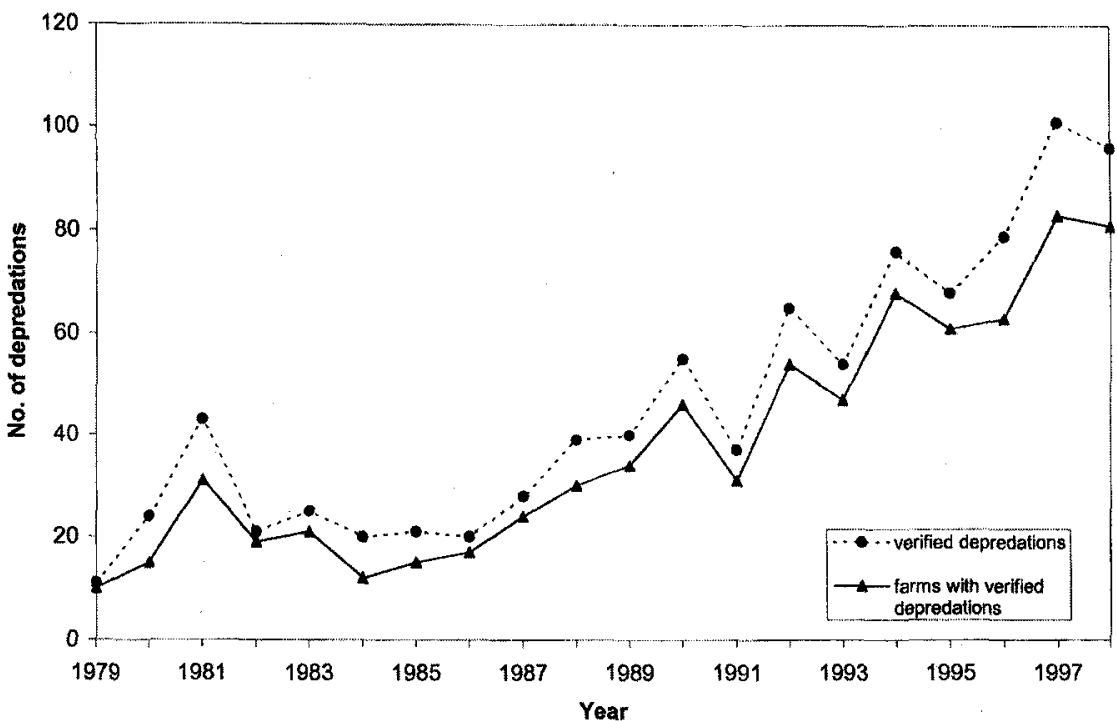

Figure 3. Numbers of verified livestock depredations and farms with verified depredations in Minnesota from 1979-1998.

was affected by wolf depredations (Table 2). During 1979-1998, the number of verified wolf depredations on livestock and the number of farms with depredations increased (Figure 3), but they increased less from 1979 to 1989 than from 1990 to 1998 (Figure 3). The percent increase in the area of depredations from 1989-1993 to 1994-1998 (10\%) was lower than that of the previous 25 -year periods (35\% and $41 \%$ ) (Table 2). The percentage of wolf range with depredations in 1998 (78\%)

Table 2. Area $\left(\mathrm{km}^{2}\right)$ of the minimum convex polygons (MCP) around the locations of verified wolf depredations in Minnesota, 1979-1998.

\begin{tabular}{|c|c|c|c|}
\hline \multirow[b]{2}{*}{ Period } & \multirow[b]{2}{*}{ Wolf range ${ }^{a}$} & \multicolumn{2}{|c|}{ Depredation MCP } \\
\hline & & Area & $\%$ of wolf range \\
\hline $1978-1979$ & 55,600 & 6,879 & 12 \\
\hline $1979-1983$ & & 42,954 & \\
\hline 1984-1988 & & $57,886^{b}$ & \\
\hline 1988-1989 & 60,178 & 53,232 & 89 \\
\hline 1989-1993 & & $81,407^{c, d}$ & \\
\hline 1994-1998 & & $89,463^{d, e}$ & \\
\hline $1987-1998$ & 80,325 & 66,883 & 78 \\
\hline
\end{tabular}

a Determined by the Minnesota DNR only during three winters, and the depredation MCPs are for the following summer.

b $35 \%$ increase since previous 5 -year period.

c $41 \%$ increase since previous 5 -year period.

d Some depredation MCPs are larger than established wolf range because of depredations by dispersing wolves outside of the established range.

e $10 \%$ increase since previous 5 -year period. decreased from 1989 (Table 2).

Causes of increase in livestock depredations

Increased density. During our study there was no evidence that wolf density increased in the primary wolf population. Aerial radiotracking and observation of wolves during winter in several areas of wolf range showed range-wide densities of about 2.8-3.3 wolves $/ 100 \mathrm{~km}^{2}$ throughout the period of study (Fuller et al. 1992, Berg and Benson 1999).

Expansion of wolf range. The number of depredations (Table 3 ) and farms with depredations outside the 1989-1998 depredation MCP increased, and they increased more outside than inside the MCP (Figure 4, Table 3). However, the number of depredations outside the MCP was less than that inside the MCP each year except 1993 (Table 3). There was no trend in the percent annual increase in depredations outside the depredation MCP (Table 3).

Wolf colonization of new areas within wolf range. The number of depredations (Table 3 ) and farms with depredations inside the 1989-1998 depredation MCP increased (Figure 4), although the proportion of each year's total inside the MCP decreased (Table 3). There was no trend in the percent annual increase in depredations inside the depredation MCP (Table 3).

Learned bebavior of wolves in an area. Three of the 4 localized farm clusters for 1979-1998 (A-C, A-D, and all farms within $10 \mathrm{~km}$ of $\mathrm{E}$ ) showed relatively stable numbers of complaints from 1982 through 1993 with increases in 1994, which remained high for 4 of the 5 years through 1998 (Figure 5). The exception was the cluster of farms within $10 \mathrm{~km}$ of farm A. This cluster showed similar trends but was high in 1989 as well.

\section{Discussion}

The number of verified wolf depredations and farms with depredations in Minnesota have been 
Table 3. Verified wolf depredations in Minnesota inside and outside of the 1989-1998 depredation minimum convex polygon (MCP).

\begin{tabular}{|c|c|c|c|c|c|c|c|}
\hline \multirow[b]{2}{*}{ Year } & \multirow[b]{2}{*}{ Depredations $^{\mathrm{a}}$} & \multicolumn{3}{|c|}{ Inside } & \multicolumn{3}{|c|}{ Outside } \\
\hline & & No. & $\%$ & $\%$ increase $^{b}$ & No. & $\%$ & $\%$ increase $\mathrm{e}^{\mathrm{b}}$ \\
\hline 1989 & 40 & 32 & 80 & $\mathrm{n} / \mathrm{a}$ & 8 & 20 & $\mathrm{n} / \mathrm{a}$ \\
\hline 1990 & 55 & 34 & 62 & 13 & 21 & 38 & 87 \\
\hline 1991 & 37 & 26 & 70 & $-d$ & 21 & 30 & - \\
\hline 1992 & 65 & 44 & 68 & 64 & 21 & 32 & 36 \\
\hline 1993 & 54 & 21 & 39 & - & 23 & 61 & - \\
\hline 1994 & 76 & 43 & 57 & 100 & 33 & 43 & 0 \\
\hline 1995 & 68 & 40 & 59 & - & 28 & 41 & - \\
\hline 1996 & 79 & 42 & 53 & 18 & 37 & 47 & 82 \\
\hline 1997 & 101 & 53 & 52 & 50 & 48 & 48 & 50 \\
\hline 1998 & 96 & 50 & 52 & - & 46 & 48 & - \\
\hline Total & 671 & 385 & 57 & & 286 & 43 & \\
\hline
\end{tabular}

a Numbers differ from those reported by WS, as reports that were noted as questionable by WS were omitted.

b Percentage of the annual increase that was inside or outside of the MCP.

c Dashes (-) indicate decreases in the total number of depredations, or depredations inside or outside the MCP.

increasing since 1979. The fact that depredations increased less from 1979-1989 than after 1989, and that the percent of wolf range with depredations was low in 1979, is likely because from 1979 to the early 1980s wolves primarily occupied forested areas where there were few farms. Our results show that contrary to our null hypothesis, the greater increase from 1989-1998 not only reflects the wolf population's expansion into more agricultural areas (Fritts et al. 1992, Fuller et al. 1992; Berg and Benson 1999; Mech 2000, 2001; Mech et al.

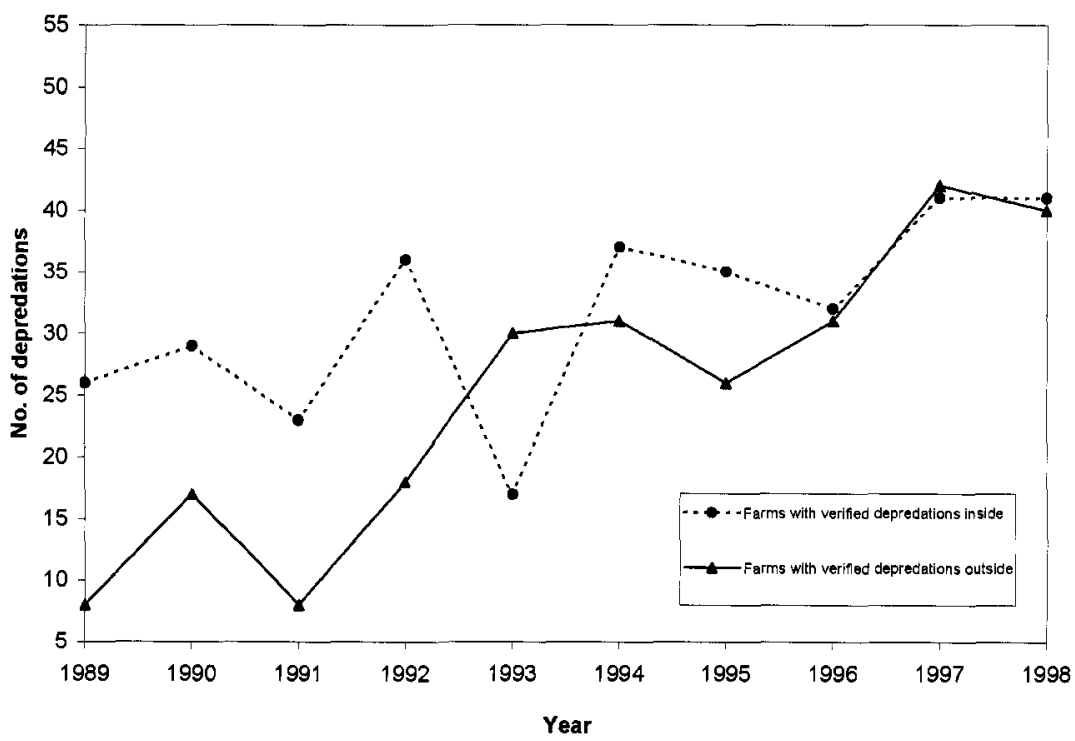

Figure 4. Number of farms with verified depredations from 1989-1998 inside and outside the 1989-1998 depredation minimum covex polygon (see Figure 1).
2000) but also probably reflects wolf colonization of new areas within wolf range as well as learning by the wolf population. Depredations and farms incurring depredations outside Minnesota's historical depredation area increased from 1989 through 1998 (Figure 4), confirming that wolf range expansion contributed to the increase in statewide depredations. However, depredations and number of farms with depredations inside the historical depredation area also increased (Figure 4), which cannot be attributed to range expansion. This finding is consistent with the hypothesis that increases in depredations were at least partly caused by wolves colonizing previously unoccupied areas within existing wolf range. This hypothesis was supported by Berg and Benson's (1999) findings that between the 1988-1989 and 1997-1998 wolf population estimates, wolves colonized 125 previously unoccupied townships within the contiguous wolf pack range identified in 1988-1989 (Fuller et al. 1992).

The possibility exists that some of the wolf depredation increase inside the historical depredation area could have been caused by wolves learning to kill or to utilize livestock more often (Linnell et al. 1999). Depredations at 4 farm clusters we studied increased in 1994 and remained high in 4 of the 5 next years. If the increase had not been due at least partly to learning, the number of depredations at these farms should have been relatively equal each year or shown no increasing trend.

The increases that did occur might have been 

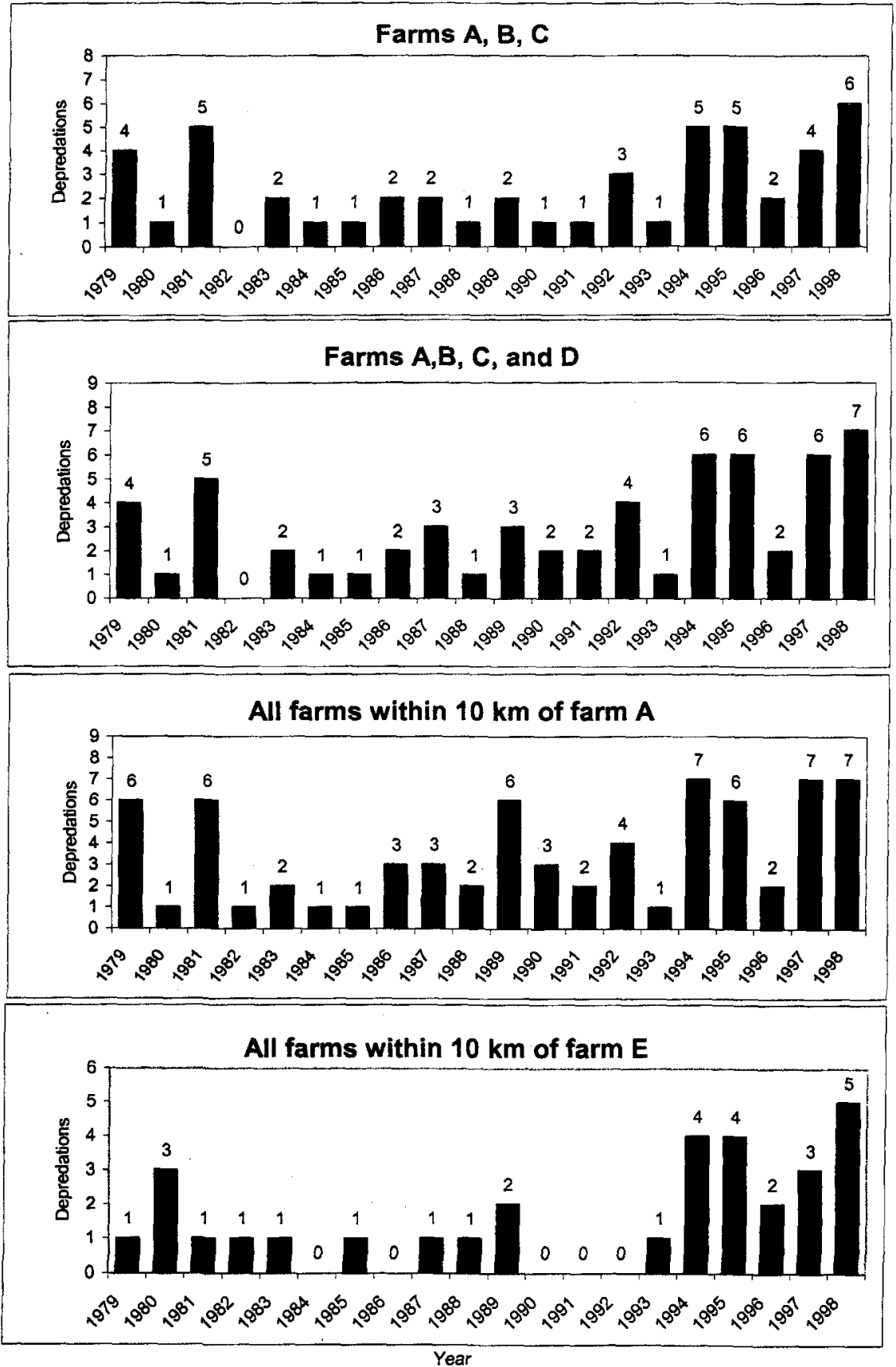

Figure 5. Number of verified livestock depredations each year from 1979-1998 for 4 clusters of Minnesota farms chosen for assessing the possibility that increased depredations resulted from wolves learning to kill livestock more frequently. incurring depredations as a cause because depredations occurred on all those farms in 1979. Additionally, the limited size of these farm clusters (diameter of $10 \mathrm{~km}$ ) and the choice of farms with a history of depredations also decreased the chance that increased depredations were caused by wolves colonizing unoccupied areas within wolf range. Possibly, the increased depredations on these farms could have been due to an increase in local wolf density, but the best evidence shows relatively stable wolf density in existing wolf range (Mech 1986, 2000; Fuller 1989; Fuller et al. 1992; Berg and Benson 1999). Conceivably, unknown factors could have caused similar results, but learning remains a prime possibility.

The proportion of depredations due to wolf colonization of new areas within existing wolf range or to learning decreased from 1989 to 1998 (Table 3 ). Despite this decrease, over half the statewide depredations in 1998 took place within long-established wolf range, indicating that the majority of the statewide depredations were not caused by range expansion. attributable to other factors, but our selection of the farm clusters reduced or eliminated most of those possibilities. All the clusters had a history of depredations since 1979, so wolf range expansion could not be a cause. The results from farm clusters $\mathrm{A}-\mathrm{C}$ eliminated an increase in number of farms

\section{Conclusions}

Increased wolf depredations from 1979 through 1998 resulted not only from wolf range expansion but also from wolf colonization of new areas in existing range and from wolves learning to kill livestock more often. As wolves continue to expand 
their range into areas of increased livestock concentrations (Mech 2000), the rise in proportion of depredations due to range expansion may continue. Despite the increase in proportion due to range expansion, the percent annual increase in depredations inside and outside the depredation MCPs from 1989 to 1998 showed no pattern, indicating that the various causes of increasing depredations were operating at varying rates (Table 3 ).

Peaks in depredations at the farm clusters in 1997 and 1998 followed 2 years of severe winters and may indicate the wolf populations' learning to kill more livestock when its natural prey was reduced. Some evidence of such learning can be seen in the large change in percent increase in depredations from 1996-1997 inside the depredation MCP (Table 3), following the severe winter of 1995-1996 when deer (Odocoileus virginianus) declined. Treves et al. (2004), on the other hand, found higher depredations where deer numbers were high, but theirs was a general model that did not consider extreme changes in deer density.

\section{Management implications}

If the trends we found continue, any further wolf depredation control in Minnesota will require personnel to cover an increasing area while also intensifying efforts in current and historical depredation areas. In other areas where wolves are proliferating, the Minnesota experience suggests that wolf depredations on livestock may increase at a greater rate than would be predicted by range expansion alone. The evidence that local wolves may be learning to kill livestock more often implies a need to remove all members of a depredating pack, including pups (E. K. Harper, University of Minnesota,. personal observation), which may require longer trapping periods or increased trapping intensity.

Acknowledgments. This research was supported by the Biological Resources Division, United States Geological Survey, and the United States Department of Agriculture's Wildlife Services, as well as a donation by V. Gates to help support the senior author.

\section{Literature cited}

BERG,W.,AND S. BENSON. 1999. Updated wolf population estimate for Minnesota, 1997-1998. Minnesota Department of Natural Resources, Grand Rapids, USA.

CHERry, S. 1998. Statistical tests in publications of the Wildlife
Society. Wildlife Society Bulletin 26:947-953.

FriTts, S. H. 1982. Wolf depredation on livestock in Minnesota. United States Fish and Wildlife Service Resource Publication 145, Washington, D.C., USA.

FrITTS, S. H., W. J. PAUL, L. D. MECH,AND D.P. SCOTT. 1992. Trends and management of wolf-livestock conflicts in Minnesota. United States Fish and Wildlife Service Resource Publication 181, Washington, D.C., USA.

FULLER, T.K 1989. Population dynamics of wolves in north-central Minnesota. Wildlife Monographs No. 105.

FUlLeR, T. K, W. E. BERG, G. L. RADDE, M. S. LeNARZ, AND G. B. JoselyN. 1992. A history and current estimate of wolf distribution and numbers in Minnesota. Wildlife Society Bulletin 20:42-55.

LinNelL, J. D. C., J. ODden, M. E. SMith, R AANes, AND J. E. SWENSON. 1999. Large carnivores that kill livestock: do "problem individuals" really exist? Wildlife Society Bulletin 27:698-705.

MECH, L. D. 1986. Wolf population in the central Superior National Forest, 1966-1985. United States Forest Service Research Paper NC-270, St. Paul, Minnesota, USA.

MECH, L. D. 1998. Estimated costs of maintaining a recovered wolf population in agricultural regions of Minnesota. Wildlife Society Bulletin 26:817-822.

MECH L. D. 2000. Historical overview of Minnesota wolf recovery. Pages 15-27 in L. D. Mech, editor. The wolves of Minnesota: howl in the heartland. Voyageur Press, Stillwater, Minnesota, USA.

MECH, L. D. 2001. Managing Minnesota's recovered wolves Wildlife Society Bulletin 29:70-77.

MeCh, L. D., E. K. Harper, T.J. Meler, and W. J. Paul. 2000. Assessing factors that may predispose Minnesota farms to wolf depredations on cattle. Wildlife Society Bulletin 28:623-629.

MoHR, C. O., AND W.A STUMPE 1966. Comparison of methods for calculating areas of animal activity. Journal of Wildlife Management 30:293-304.

PAUL, W. J. 1998. Wolf depredation on livestock in Minnesota annual update of statistics 1997. United States Department of Agriculture, Grand Rapids, Minnesota, USA (unpublished).

PAUL, W. J. 2000. Wolf depredation on livestock in Minnesota annual update of statistics. 1999. United States Department of Agriculture, Grand Rapids, Minnesota, USA (unpublished).

Treves, A., L. Naughton-Treves, E. K. Harper, D. J. Mladenoff, R. A. Rose, T. A. Sickley, AND A. P. Wydeven. 2004. Predicting human-carnivore conflict: a spatial model derived from 25 years of data on wolf predation on livestock. Conservation Biology 18: 114-125.

United States Fish and Wildife Service. 1978. Recovery plan for the eastern timber wolf. United States Fish and Wildlife Service, Washington, D.C., USA.

United States Fish and Wildlife Service. 1992. Recovery plan for the eastern timber wolf. United States Fish and Wildlife Service, Twin Cities, Minnesota, USA.

Untted States Fish and Wildife Service. 2003. Gray wolf eastern distinct population segment. United States Fish and Wildlife Service, Twin Cities, Minnesota, USA.

Elizabeth K. (Liz) Harper (photo) received her B.A. from Moorhead State University and her M.S. from the University of Minnesota, St. Paul. Over the last 15 years, she has worked on a variety of projects, including the black-footed ferret reintroduction in Wyoming, the Minnesota wolf project, and various small-mammal and herpetofaunal projects for Minnesota's County Biological Survey (MCBS), the Smithsonian, The School for Field Studies, Moorhead State University, and the University 
of North Dakota. She is currently an animal survey specialist with MCBS. Her interests include amphibian, reptile, and small-mammal ecology, and wolf-livestock conflicts. L. David (Dave) Mech is a senior research scientist for Northern Prairie Wildlife Research Center, Biological Resources Division, United States Geological Survey (USGS), and an adjunct professor at the University of Minnesota. He obtained his B.S. in wildlife conservation from Cornell University and his Ph.D. in wildlife ecology from Purdue University. He has studied wolves and their prey for over 45 years and published several books and numerous articles about them. Among the awards Mech has received is The Wildlife Society's Aldo Leopold Award. William J. (Bill) Paul is a district supervisor for the United States Department of Agriculture's Wildlife Services program in Minnesota, where he coordinates federal wolf depredation control activities. He received his B.S. in biology from Moorhead State University and has been involved in wolf research and control programs in Minnesota for 30 years.

\section{Associate editor. Crête}

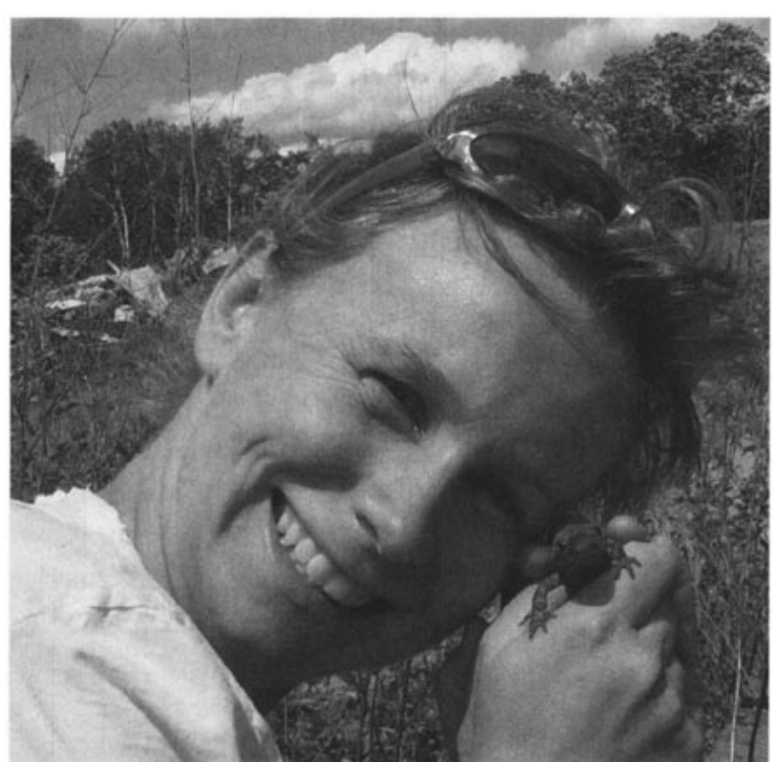

